\title{
Study on the Application of Standardization in Management Consulting Industry in China
}

\author{
Linfeng $\mathrm{Wu}$
}

China National Institute of Standardization, Beijing 100191, China.

Keywords: Management consulting; existing problem; development experience; standard system.

\begin{abstract}
This article analyzes the current state of Chinese management consulting industry and, specific to problems existing in the development process of Chinese management consulting industry by drawing development experience from advanced countries in this field, proposes systematic plans for the standard system of Chinese management consulting industry, explores a feasible route for the application of standardization in Chinese management consulting industry, and provides specific plans and programs.
\end{abstract}

\section{Introduction}

In face of severe competition and complex and changeful external environment on the one hand and complicated and thorny problems in internal operating mechanism and management on the other hand, leaders of both enterprises and governments may need advices provided by experts with more expertise, more extensive knowledge structure and more sufficient information resources, so that the thinking and understanding of such leaders may be enlightened, the decisions made by them may be more forward-looking, scientific and accurate, and the behaviors of them may be more consistent with laws of market economy. According to a research report of IBIS WORLD, the total revenue of the global management consulting industry in 2016 had reached 604 billion dollars and the annual growth rate of 2011-2016 reached 5.1\% [1]. The emerging management consulting industry in China was accompanied with the rise of market economy. Although having made great achievements, this industry still has certain problems. This article, based on the thinking of standardization, plans a standard system for management consulting specific to the problems currently existing in this industry by combining the current state of application of standardization in management consulting, so as to lead and regulate the management consulting industry of China, facilitate it to develop healthily and thereby, enhance its core competitiveness and economic benefits.

\section{Development State of the Management Consulting Industry of China}

From none to one, from small to large, and from naivety to maturity, the consulting industry of China, although taking a tortuous road, has certainly created significant social and economic benefits. China's management consulting industry started at the beginning of the 1980s in the form of consultancy companies; the government began to build consultation enterprises mainly in the fields of investment, technology and financial consulting in the late 1980s. With the Chinese economy's development towards marketization, a group of foreign-funded and private "information consultation" and "market research" companies sprang up in the early 1990s, providing standardized consulting services for enterprises. In the mid-1990s, foreign management consulting firms entered into China massively, such as McKinsey, Andersen, Roland Berger, BCG, Gallup and Price Waterhouse Coopers, since then, the management consulting industry has entered the stage of professional development. Some domestic management consulting firms emerged in the late 1990s, such as Pilot, Han Consulting, Bexcel Management, GEI, allpku, and Shidai Ruicheng. At the beginning of the 21st century, the management consulting industry has devoted to the combination of the most advanced management thought and management model and modern IT technical means, providing comprehensive and systematic service for enterprises.

With the reform of the economic system and after 30 years of development, Chinese consulting industry has begun to take shape. The annual turnover of this industry is growing at an annual speed 
of over 20\%. Today, China has almost all kinds of consulting institutes, including, engineering, technology, management, decision-making, investment, and finance consultation and so forth. As of the year of 2013, China had approximately 195,000 consulting institutes (including investigation agencies) with qualification of enterprise legal person [2], of which about 200 are strongly competitive and well-known institutes, such as the Development Research Center of the State Council, Center for Management Science of Peking University, Puzhi Consulting, China International Economic Consultants and so forth. There are generally two categories of consulting institutes according to subordination relationship: the first category, which consists of affiliates to administrative departments, accounting for nearly $40 \%$ in the industry. Institutes of this category often lack independent operating capacity and mainly depend on projects allocated by their superior administrative departments. The other category, including consulting entities of state-owned companies, often has flexible operating method, higher efficiency and also, higher rate of elimination.

As of 2017, Chinese management consulting institutes are classified into the following three kinds by their scales and operating features.

Class I: Consulting firms. This kind of enterprises has a certain scale with clear product lines and adopts corporate operation.

By consulting directions, this kind can be further divided into comprehensive consulting companies, professional consulting companies and consulting companies specialized in a certain industry. By source of capital, this kind can be divided into international consulting companies and fast-growing local companies.

Class 2: Studios. This kind of companies often has an intermediate scale and consists of about 30 staff. These companies are featured by their dependence on a certain capable person, expert or iconic boss or expert, but not on their scale.

Class 3: Private consulting teams, which mainly consist of less than 10 people. This kind of consulting firms accounts for an exceptionally large portion in the market.

According to the statistical data of 2016 from zwzyzx.com, 75\% of American enterprises keep business cooperation with consulting firms, and 50\% of Japanese enterprises improve their management with the help of consultants. At present, some internationally famous consulting institutes have already entered China and become active in China. According to incomplete statistics, there are more than 200 foreign institutes and their turnover has already accounted for half of the Chinese management consulting market. They position themselves, mostly, in high-end market. They have good service concepts, strict management systems, complete information systems, high work efficiency and strong market ability. In contrast, the majority of domestic management consulting institutes lag far behind in terms of operating mechanism as well as service quality.

\section{Problems Existing in the Development of the Management Consulting Industry of China}

\subsection{Lack of Industrial Norms and Supporting Environment}

In retrospect of the development process of Chinese management consulting industry in the past 30 years, we can find that this industry generally developed along an unorganized way with unordered competition. It lacks supporting environment and industrial norms and the management is in need of enhancement.

(1) Lack of coordination by industrial organizations

There is not yet any unified industrial association for this industry. China has, in total, more than 30,000 various consulting companies and more than 80,000 full-time employees working in this industry; however, this industry has not yet established its own industrial association. There are only several associations, such as China National Association of Engineering Consultants, China Association of Engineering Consultants, China National Association of Technology Consultants and so forth, most of which were founded in the 1990s. Such associations have obvious Chinese characteristics and are generally affiliated to ministries and commissions. The members of them are mostly design units within their own systems. The membership conditions and contents of their rules and systems are too general and their binding force is also insufficient. Such associations do not really exert the function of assisting government management, but mainly work for information exchange 
and personnel training. They also have conflicts in understanding of management consulting enterprises.

(2) Lack of information exchange platform

Because of the absence of an industrial association, there are hardly any information exchange platforms for management consulting enterprises and seldom profound investigations and studies on problems of management consulting industry against the background of market economy and the reasons of such problems. Some experts once pointed out that one important reason for unsatisfactory operation of Chinese enterprises was the absence of necessary supporting theories and methodologies. The generation and development of management theories and management consulting in western advanced countries were almost synchronous. Around 50\% of the top 500 enterprises of the world have established long-term partnership with internationally famous management consulting companies and $100 \%$ of the top 500 companies have received more than one time of management consulting services.

\subsection{Lack of Talent Pool}

In the famous US consulting company Rand, experts account for $88 \%$ of the total staffs; engineering and technical staffs account for $28 \%$, physicists account for $11 \%$, mathematicians account for $14 \%$, planning and statistic experts account for $9 \%$, economists account for $15 \%$, sociologists account for $6 \%$ and operational research experts account for $4 \%$. Qualified experts from different fields account for more than $80 \%$ of the total staffs; the proportion of professionals with master or doctor degree exceeds $70 \%$. However, in China, most of our management consulting companies are in short of accumulation of talents. They have hardly any senior experts and the job changing rate of current excellent talents still remains high. Most of the consultants in China formerly worked in universities, research units, engineering design departments and information research and analysis departments. Although having a wealth of professional experience, they are not specialized in management consulting. The main problems for consultants currently are their narrow and seriously backward knowledge, their lack of modern management consulting awareness as well as their insufficient awareness of strategic views, market competition concepts, system concepts and the sense of responsibility. As shown by data, there are in total 72 persons with the qualification of Certified Management Consultant, 105 senior management consultants, and 184 management consultants in the 1,199 management consulting institutes across Zhejiang Province. There are only 0.3 management consulting personnel with occupational qualification per one management consulting institute on average.

\section{Application of Standardization in Management Consulting Industry}

Since the year of 2003, Italy has successively promulgated 6 standards for management consulting. In 2011, Europe issued the EN 16114:2011 Management Consultancy Services, and countries, including UK, Germany, France, and Sweden, also formulated their own standards for management consulting services on the basis of the European standard. The European standard EN 16114 for management consulting service is widely applied in the management consulting industry and functions as an important propelling force for the sound development and prosperity of the European management consulting industry. In addition, ISO 20700 Guidelines for Management Consultancy Services promulgated in 2017 plays a demonstrative role in the world.

Nevertheless, China does not have any national standard concerning management consulting at present. There is only one local standard. Relevant retrievable domestic and foreign standards are as shown in Table 1. Some of the more normative enterprises have recognized the important role played by standards in regulating management consulting process and improving consulting quality, and a small portion of enterprises have adopted such standards. The formulation and implementation of such standards plays a regulative role to a certain extent. However, as the range of implementation is greatly limited and such standards are not systematic, they can hardly manage to regulate the whole industry. 
Table 1. Standards concerning the management consulting industry

\begin{tabular}{|c|c|c|c|c|}
\hline Standard NO. & Issuing unit & Name & English name & $\begin{array}{c}\text { Date of } \\
\text { issuance }\end{array}$ \\
\hline ISO 20700-2017 & ISO & $\begin{array}{l}\text { Guidelines for management } \\
\text { consultancy services }\end{array}$ & $\begin{array}{l}\text { Guidelines for management } \\
\text { consultancy services }\end{array}$ & 2017 \\
\hline $\begin{array}{l}\text { UNI EN 16114-2011 } \\
\text { EC 1-2012 }\end{array}$ & IT-UNI & Management consultancy services & Management consultancy services & 2011 \\
\hline DB44/T 1023-2012 & CN-DB44 & $\begin{array}{l}\text { Specification for qualification assessment of } \\
\text { enterprise management advisory and training } \\
\text { institutions }\end{array}$ & $\begin{array}{l}\text { Specification for qualification assessment of } \\
\text { enterprise management advisory and training } \\
\text { institutions }\end{array}$ & 2012 \\
\hline UNI EN 16114-2011 & IT-UNI & $\begin{array}{l}\text { Management consultancy services } \\
\text { Management consulting Guide for the }\end{array}$ & $\begin{array}{l}\text { Management consultancy services } \\
\text { Management consulting Guide for the }\end{array}$ & 2011 \\
\hline UNI 11369-2010 & IT-UNI & $\begin{array}{c}\text { Classification of management consultants } \\
\text { based on skill systems }\end{array}$ & $\begin{array}{l}\text { Classification of management consultants } \\
\text { based on skill systems }\end{array}$ & 2010 \\
\hline
\end{tabular}

Due to the lack of unified and systematic industrial standards and complete industrial selfdiscipline, the quality of institute construction and personnel are greatly varied, which seriously hampers the improvement of quality of consulting service. Currently, management consulting institutes in China are mainly middle and small in size. Many local management consulting companies have only simple structure and vague division of work, which prevents them from undertaking large and high-end businesses. At the same time, as there is no unified and systematic industrial standard, it is difficult to improve the standardized level of institute construction and talent training in management consulting industry. The backwardness of the standardization of Chinese management consulting industry directly leads to the insufficiency of local enterprises in institute construction and talent training and thus seriously influences the enhancement of the service quality of the industry.

\section{Study on the Establishment of a Standard System for Management Consulting}

The management consulting industry is in urgent need of establishing a standardization system to lead, regulate and enhance industrial development. As Chinese enterprises seek to go global, they are pressed for support from standardization of management consulting. Therefore, improvement of service quality and ability is the development trend and inevitable requirement for the management consulting industry. Establishment of relevant national standard systems for management consulting is the key link to propel industrial development and to improve industrial competitiveness.

\subsection{Analysis of Standardization of Management Consulting}

Currently, the global service industry has shown the trend of information-orientation, internationalization and standardization, and standardization has become an important feature which differentiates modern service industry from traditional service industry. Management consulting has relatively high professional attributes and complicated work procedures. The generalization of standardization will become an important support for the reinforcement of industrial core competitiveness and the construction of harmonious market environment. The key reason for management consulting giants in advanced countries to gain strong market competitiveness is their owning of "important standards". The results of standardization in terms of consulting procedures and service quality control of global renowned management consulting companies, such as McKinsey, are not only translated into discourse systems and decision-making systems for enterprises to connect their interests and to be compatible with others; they've also evolved into game rules for competition in the international market. As shown in researches, the European application of standards concerning management consulting has contributed significantly to the sound development and prosperity of European management consulting industry in recent years. As a late starter, the management consulting industry of China is facing various challenges both internally and externally, therefore, it is urgently in need of standardization, so as to provide a drive for the development of the industry. More specifically:

In terms of management consulting process. The professionalism of management consulting is reflected in all links of consulting procedures. Realizing orderly and efficient process before, during and after the management consultation via standardized methods may help to improve the consulting quality and, at the same time, lay a foundation for the normalization of the development of the industry. 
In terms of management consulting institutes. The qualification level of consulting institutes is closely related with the quality of management consulting service. In order to ensure the overall quality of Chinese management consulting service, it is necessary to establish instructive or assessment standards for management consulting institutes and to build up corresponding assessment mechanism. We need to structure and perfect assessment indicator system for institutes and formulate assessment methods in a scientific way, so as to perfect incentive and restraint mechanism for institutes and inject more energy and vigor to the development of the industry.

In terms of staffs working in the management consulting industry. The professional quality of the staffs working in the management consulting industry plays a decisive role in the quality of management consulting service. Therefore, it is necessary to carry out standardization work concerning evaluation, training and performance review for staffs working in the management consulting industry, so as to improve the overall level of the staffs. At the same time, such standardization work may also provide guidance and reference for people who intend to enter this industry.

In terms of management consulting quality. As enterprises become more concern about the quality of management consulting service, the standardization of management consulting quality also becomes a key factor to increase the public recognition of the industry. Besides encouraging personalized service, establishing relevant standards for basic components or links of product consulting also plays a vital role in ensuring the overall service quality of the industry.

\subsection{The Construction of the Standard System for Management Consulting}

The implementation of a management consulting business needs guidance and regulation by certain consulting standards; however, the development and enhancement of the whole consulting industry needs overall planning and guidance of a standard system. China has been preparing to build a technical committee for management consulting; but, the construction of the system of management consulting is really a systematic project involving various business activities. Management consulting covers all aspects of business activities, including strategy consulting, human resource management, salary management, performance management, information security, finance management, compliance management, risk management, certification services and so forth and involves a variety of links in consulting services from content confirmation of consulting service, process control of consulting service to the delivery of consulting products and evaluation of consulting services. Therefore, to build up a standard system for management consulting, we need to analyze the characteristics and principles of management consulting services in a systematic way; determine the general principles and requirements of the consulting service system; analyze mutual relation between various activities of management consulting services; and structure a standard system framework for management consulting, so as to enhance the efficiency of various consulting items, reduce the barriers in management consulting services for trading across different industries and lower the risks of management consulting tasks.

Based on the business activities covered by management consulting, this study proposes a chart of national standard system of professional fields related to management consulting, as shown in Figure 1. 


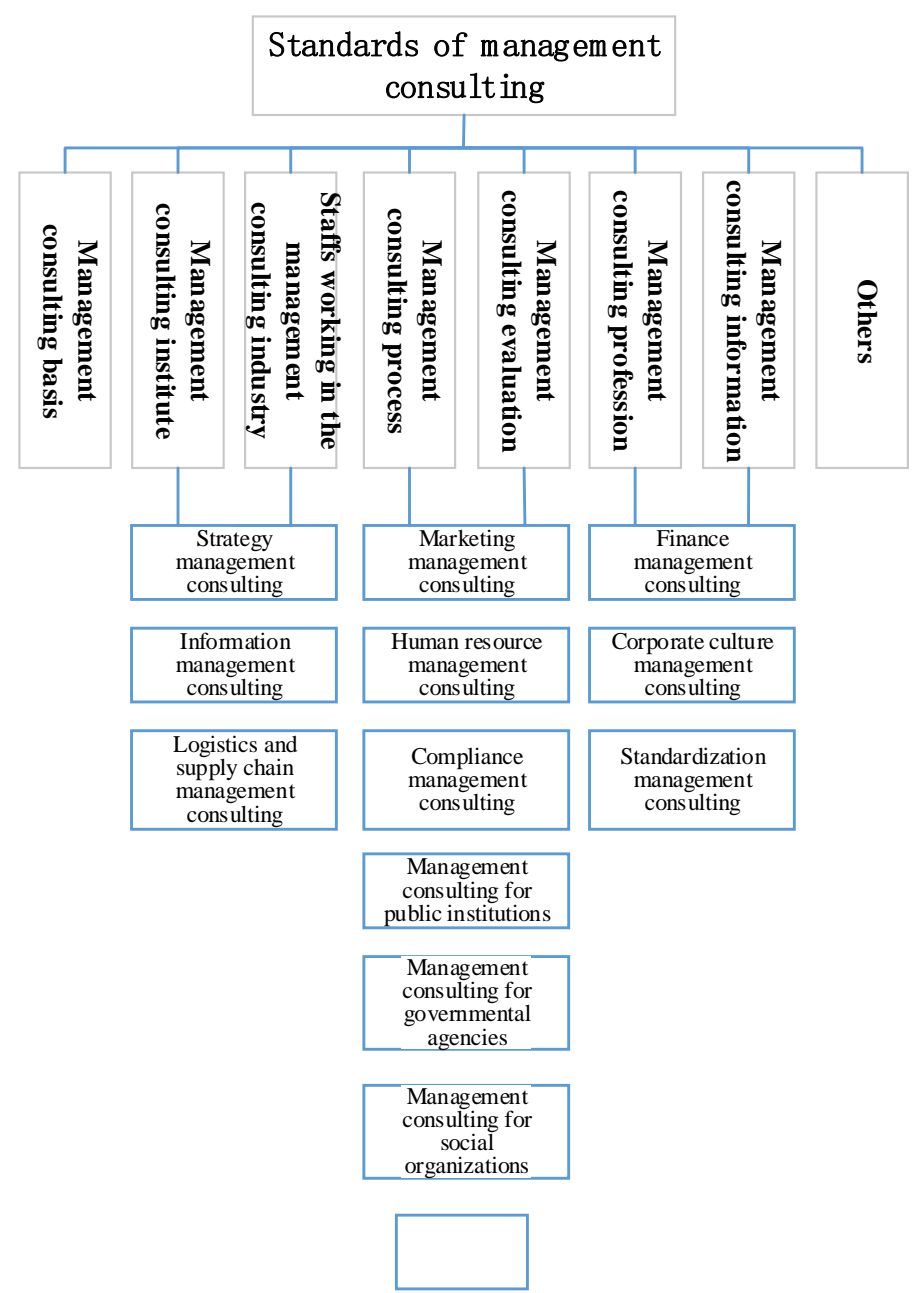

Fig.1. Chart of National Standard System of Related Professional Fields

It proposes to launch standardization work in seven main fields including "management consulting basis", "management consulting institute", "staffs working in the management consulting industry", "management consulting process", "management consulting evaluation”, "management consulting profession" and "management consulting information". Among them, "management consulting basis" may include general basic standards and special basic standards. This field is mainly responsible for the implementation of basic and general standardization work in the management consulting field and formulating standards pertinent to terminology, classification, signs and marks, etc. "Management consulting institute" is mainly responsible for standardization work concerning the qualification, human resource, social responsibility and environmental protection and compliance of management consulting institutes. The field of "staffs working in the management consulting industry" is mainly responsible for standardization work concerning the competency, training and performance assessment of staffs working in the management consulting industry. "Management consulting process" is mainly responsible for standardization work which is related to management consulting rules, compliance regulations, delivery of results and quality requirements, and may include standards for plan design, standards for guidance on implementation, project evaluation standards, contract regulations, guidance on delivery, guidance on after-sales services, and requirements on service quality. "Management consulting evaluation" is mainly responsible for standardization work concerning the evaluation of management consulting quality, the evaluation of management consulting institutes and the evaluation of staffs of management consulting industry. "Management consulting profession" mainly involves the implementation of standardization work concerning management consulting in different professional fields. Specifically, it involves, by professions, strategy management consulting, marketing management consulting, finance management consulting, information management consulting, human resource management consulting, compliance management consulting, standardization management consulting, qualification assessment management consulting, corporate culture management consulting, and logistics and supply chain 
management consulting and involves, by users, management consulting for governmental agencies and public institutions, management consulting for social organizations, etc. "Management consulting information" is mainly responsible for standardization work concerning the collection and exchange of management consulting information, management consulting information system and management consulting basis. As shown in Table 2, national standards in the above seven fields may better meet the current demands of Chinese management consulting standardization work.

In addition, in consideration of the systematisms and scalability of the standard system, if any standardization work concerning management consulting we may encounter in the technical and cognition development process in the future is not covered by the above seven fields, such work may be categorized in the field of "Others".

Table 2. Standardization Worksheet Scheduled to be Carried out in Different Fields

\begin{tabular}{|c|c|c|}
\hline NO. & Type of standard & Related standards \\
\hline 1 & $\begin{array}{l}\text { Management } \\
\text { consulting basis }\end{array}$ & Terminology; classification; signs and marks \\
\hline 2 & $\begin{array}{l}\text { Management } \\
\text { consulting } \\
\text { institute }\end{array}$ & $\begin{array}{l}\text { Qualification requirement; HR requirement; requirements on social } \\
\text { responsibility and environmental protection; compliance guidance }\end{array}$ \\
\hline 3 & $\begin{array}{l}\text { Staffs working in } \\
\text { the management } \\
\text { consulting } \\
\text { industry }\end{array}$ & $\begin{array}{c}\text { Requirement on industry staffs; guidance on training; guidance on } \\
\text { performance assessment. }\end{array}$ \\
\hline 4 & $\begin{array}{c}\text { Management } \\
\text { consulting process }\end{array}$ & $\begin{array}{l}\text { Standards of plan design; standards of implementation guidance; standards } \\
\text { of project evaluation; contract regulations; guidance on delivery; guidance } \\
\text { on after-sales services; requirements on service quality }\end{array}$ \\
\hline 5 & $\begin{array}{l}\text { Management } \\
\text { consulting } \\
\text { evaluation }\end{array}$ & $\begin{array}{l}\text { Principles and methods of evaluation; evaluation indicators or indicator } \\
\text { system; evaluation procedures and requirements; guidance on institute } \\
\text { evaluation; guidance on the evaluation of industry staffs }\end{array}$ \\
\hline \multirow{2}{*}{6} & \multirow{2}{*}{$\begin{array}{l}\text { Management } \\
\text { consulting } \\
\text { profession }\end{array}$} & $\begin{array}{l}\text { Standards of marketing management consulting; standards of } \\
\text { finance management consulting; standards of information } \\
\text { management consulting; standards of human resource } \\
\text { management consulting and so forth }\end{array}$ \\
\hline & & $\begin{array}{l}\text { Standards of management consulting for governmental agencies; } \\
\text { standards of management consulting for public institutions; } \\
\text { management consulting for social organizations }\end{array}$ \\
\hline 7 & $\begin{array}{l}\text { Management } \\
\text { consulting } \\
\text { information }\end{array}$ & $\begin{array}{l}\text { Standards of information basis; standards of information collection; } \\
\text { standards of information exchange; standards of information system }\end{array}$ \\
\hline
\end{tabular}

\section{Conclusion}

Management consulting is an important part of modern service industry. The formulation and application of relevant standards in the field of foreign management consulting has effectively propelled the normalized development and service update of its management consulting. The standardization work of management consulting is an emerging area with extremely wide coverage among domestic standardization activities. The development of Chinese management consulting industry has gone through the germination period and is right now in an important transitional period from chaos to clearness and professionalization. This article summarizes the whole process of management consulting and plans and designs the standard system for management consulting, which functions as a guide for the normalized development of the management consulting industry. 


\section{Acknowledgements}

Foundation Project: The study in this article is funded under the President Foundation of CNIS (NO.:572016Y-4675), the standardized public opinion monitoring analysis report of SAC(572016B4880), and the Construction of Recommending Standard Systems and Report on the Development of Standardization (NO.: 572014B-3590, 572016B-4628) of SAC.

\section{References}

[1]. IBIS World. Global Management Consultants: Market Re-Search Report[R/OL.]. [2017-06-23]. Http://www.ibis-world.com/industry/global/global-management-consult-ants.html

[2]. Liu Yi, Zhao Song. Study and Judgment of the Development Trend of Management Consulting Industry of China [J]. Economic Vision. Vol. 8, (2015), p. 274. 